\author{
Krzysztof Kaszewski \\ ORCID: 0000-0002-8789-2405 \\ Uniwersytet Warszawski
}

DOI 10.19195/1642-5782.17(27).4

\title{
Odmiana polskich nazw miejscowych w edukacji szkolnej — jak i po co?
}

Fleksji ${ }^{1}$ polskich nazw miejscowych (czyli nazw polskich miast i wsi ${ }^{2}$, dalej: PNM) przyglądam się z perspektywy metodycznej z trzech głównych powodów:

a) wiąże się ona $\mathrm{z}$ wieloma trudnościami nieobecnymi przy odmianie innego typu nazw pospolitych i własnych, między innymi ze względu na mnogość paradygmatów i nieregularności, utrudniających pracę typowymi metodami dedukcyjnymi (poznanie ogólnych zasad + ćwiczenia w ich stosowaniu);

b) jest nowym zagadnieniem w podstawie programowej obowiązującej od 24 lutego $2017 \mathrm{roku}^{3}$, przez co powstało dotąd stosunkowo mało pomocy edukacyjnych ${ }^{4}$ i pomysłów metodycznych, z których mogliby korzystać uczniowie i nauczyciele;

1 Terminu fleksja używam w artykule jako zamiennika określenia odmiana, nie zaś na oznaczenie działu morfologii.

2 Nazwy miejscowe rozumiem w niniejszym artykule jako nazwy miast i wsi — tak jak Ewa Rzetelska-Feleszko, por. eadem, Nazwy geograficzne, [w:] Współczesny język polski, red. J. Bartmiński, Lublin 2001, s. 414. Inaczej rzecz ujmuje Wielki słownik poprawnej polszczyzny, w którym nazwy miejscowe są pojęciem szerszym, obejmującym wszystkie typy nazw geograficznych — por. Wielki słownik poprawnej polszczyzny, red. A. Markowski, Warszawa 2008, s. 1632-1635.

3 W klasie VII-VIII zapisano: „uczeń [...] rozpoznaje nazwy osobowe i miejscowe, rodzaje nazw miejscowych, używa poprawnych form gramatycznych imion, nazwisk, nazw miejscowych i nazw mieszkańców", Rozporządzenie Ministra Edukacji Narodowej z dnia 14 lutego 2017 r. w sprawie podstawy programowej wychowania przedszkolnego oraz podstawy programowej ksztatcenia ogólnego dla szkoły podstawowej, w tym dla uczniów z niepełnosprawnościa intelektualna w stopniu umiarkowanym lub znacznym, ksztatcenia ogólnego dla branżowej szkoły I stopnia, kształcenia ogólnego dla szkoły specjalnej przysposabiajacej do pracy oraz kształcenia ogólnego dla szkoty policealnej (Dz.U. z 2017 r. poz. 356, s. 67).

${ }^{4}$ W styczniu 2019 roku zagadnienie poruszały cztery serie podręcznikowe dla szkół podstawowych, dopuszczone do użytku szkolnego na podstawie opinii rzeczoznawców MEN-u. 
c) wbrew pozorom stwarza okazję do realizacji również innych istotnych celów edukacji polonistycznej (i nie tylko), jeśli przestanie się widzieć to zagadnienie wąsko, ściśle pragmatycznie (czyli koncentrować na opanowaniu sposobu odmiany różnych PNM).

$\mathrm{Na}$ wstępie artykułu przypominam główne trudności związane z odmianą PNM, które decydują o specyfice dydaktyki tego zagadnienia. W drugiej części proponuję różne sposoby pracy i rozmaite typy ćwiczeń, realizujących nie tylko (a może nie przede wszystkim) cel ściśle sprawnościowy (używanie form PNM uznawanych za poprawne), lecz także cele bardziej uniwersalne (między innymi związane $\mathrm{z}$ radzeniem sobie $\mathrm{z}$ nieuniknionymi trudnościami językowymi oraz rozwojem logicznego myślenia). Przy każdym ćwiczeniu dokładnie objaśniam, jakie umiejętności ma ono uaktywniać i rozwijać oraz dlaczego znalazły się w nim akurat te, a nie inne przykłady.

\section{Główne przyczyny kłopotów z odmianą nazw miejscowych}

Odmiana PNM sprawia więcej kłopotów niż posługiwanie się nazwami pospolitymi czy nazwami własnymi innego typu (na przykład polskimi imionami czy nazwiskami), a nawet - paradoksalnie - obcymi nazwami miejscowymi ${ }^{5}$. Przyczynami tego stanu są czynniki różnego typu, między innymi systemowe, historyczne czy społeczne.

Po pierwsze, podstawowa postać słownikowa PNM, czyli mianownik, niejednokrotnie nie pozwala jednoznacznie wskazać rodzaju gramatycznego i/lub liczby danej nazwy, przez co nie można wybrać stosownego sposobu odmiany. Nazwy Chodzież czy Trzebież mają rodzaj żeński, mimo że kończą się spółgłoską, co w polszczyźnie oznacza najczęściej rodzaj męski. Z kolei nazwa Poryte może wskazywać na liczbę pojedynczą (i wtedy odmienia się jak Zakopane mieszkam w Porytem) albo liczbę mogą (wówczas odmieniałaby się jak Końskie — mieszkam $w$ Porytych). W wielu sytuacjach są możliwe (choć z różnym prawdopodobieństwem) dwa wzorce fleksyjne, a czasem nawet trzy lub cztery — i na podstawie mianownikowej formy nazwy nie sposób zdecydować, który jest w danym przypadku właściwy.

Po drugie, w wielu wypadkach nawet ustalenie rodzaju i liczby nazwy nie usuwa wahania, czy należy zastosować odmianę rzeczownikową, czy przymiotnikową. Trudności te $\mathrm{w}$ znacznej mierze wynikają z niemożności odwołania się do znaczenia słowa - nazwy własne znaczą w sposób specyficzny (w niektórych ujęciach nie znaczą wcale). Kłopot dotyczy na przykład nazw zakończonych na

5 Znaczna część nazw obcych pozostaje nieodmienna, a te, które się odmieniają, zwykle jasno wpisują się w określony polski wzorzec fleksyjny. 
-owa, które mogą odmieniać się jak przymiotnik typu surowa (tak odmieniają się na przykład nazwy Limanowa, Wiśniowa, Poniatowa) lub jak rzeczownik typu głowa (tak odmieniają się na przykład nazwy Częstochowa, Włoszczowa, Wschowa).

Po trzecie, istnieją liczne nieregularności i niekonsekwencje w odmianie podobnie zbudowanych nazw. Na przykład identycznie zakończone nazwy Zgłobień i Lubień inaczej tworzą formy dopełniacza (Zgłobnia, ale Lubienia); analogicznie zbudowane nazwy Kołobrzeg i Tarnobrzeg dają odmienne formy dopełniaczowe Kołobrzegu i Tarnobrzega.

Po czwarte, nazwy miejscowe niekiedy odmieniają się inaczej niż nazwy pospolite o analogicznych właściwościach gramatycznych (identyczne zakończenie, ten sam rodzaj gramatyczny, jednakowa liczba) lub nazwy pospolite tożsame formalnie (nie licząc różnicy w pisowni — od małej lub wielkiej litery). Przykładem takiej bardzo mylącej homonimii mogą być nazwy Jeziora lub Leszcze. Nazwę Jeziora spontanicznie odbiera się jako mianownik liczby mnogiej analogiczny do odpowiedniej formy rzeczownika pospolitego jezioro, co jest przydatne w odniesieniu do nazwy wsi w Wielkopolskiem (poprawnie na przykład jade do Jezior), ale zawodzi w odniesieniu do wsi w województwie mazowieckim - tu przywołana nazwa ma liczbę pojedynczą, jest rodzaju żeńskiego i w związku z tym odmienia się analogicznie do rzeczowników typu nora (poprawnie na przykład jadę do Jeziory). Z kolei nazwa Leszcze (wieś w województwie łódzkim) nie jest liczbą mnogą od leszcz, lecz ma rodzaj nijaki i liczbę pojedynczą — w efekcie odmienia się jak na przykład oblicze.

Po piąte, ta sama nazwa miejscowa może odmieniać się inaczej w odniesieniu do różnych miejscowości. Powtarzanie się nazw miejscowych jest w Polsce częste (mamy między innymi dwadzieścia sześć Warszaw, cztery Krakowy i trzy Poznanie) i nierzadko wiąże się z odmiennością fleksyjną. Typowe jest na przykład zróżnicowanie form dopełniacza w odniesieniu do nazw w liczbie mnogiej — najczęstsza polska nazwa miejscowa Piaski (ponad 270 wystąpień) przyjmuje w różnych miejscach jedną w dwóch form dopełniacza: Piasek lub Piasków. Nazwa Marki w różnych miejscach może dać w dopełniaczu formę Marek lub Marków, nazwa Strzelce - Strzelec lub Strzelc.

Po szóste, w odmianie wielu PNM uwidoczniają się zjawiska historyczne, które są nieobecne bądź rzadkie w odmianie nazw pospolitych. Dobrym przykładem jest miękkotematowa odmiana nazw typu Radom, Oświęcim (trudno wskazać analogie wśród powszechnie znanych rzeczowników pospolitych) czy też Wrocław, Wodzisław (tak jak pospolite paw, żuraw — jednak zdecydowana większość rzeczowników pospolitych zakończonych na -aw ma odmianę twardotematową, na przykład staw, przejaw, zestaw).

Po siódme, sposób odmiany nazw miejscowych nierzadko kształtują zwyczaje lokalne, które mogą być sprzeczne z wariantami systemowymi, a są silnie rozpowszechnione w danej społeczności i akceptowane przez dobrze wykształconych, wrażliwych językowo użytkowników polszczyzny. Na przykład w Tychach 
i ich okolicach forma dopełniaczowa Tychów ma wyraźną przewagę nad „,bardziej systemową" formą Tych ${ }^{6}$. W związku z tym nawet dobra znajomość zasad „gramatyki ogólnej" nie gwarantuje poprawnego używania nazw miejscowych, tym bardziej że wielu językoznawców daje pierwszeństwo formom lokalnym i regionalnym (słowniki zaś asekuracyjnie notują oboczność form).

Po ósme, liczne PNM, zwłaszcza małych miejscowości, są nieopracowane poradnikowo. Mnogość nazw (wykaz urzędowych nazw miejscowości i ich części liczy ponad 103 tysiące pozycji ${ }^{7}$ ) sprawia, że trudno opisać każdą z osobna, mimo że byłoby to użyteczne ze względu na liczne indywidualności i nieregularności odmiany, uwarunkowane językowo i pozajęzykowo. Największy słownik poświęcony polskim nazwom miejscowym ${ }^{8}$ omawia ,jedynie” 7400 jednostek, a wspomniany wykaz urzędowy, mimo że zawiera wszystkie nazwy, podaje tylko formy mianownika i dopełniacza.

Naturalną konsekwencją kłopotów z odmianą PNM są kłopoty z dotyczącą ich dydaktyką. Wymienione wyżej czynniki sprawiają, że nauczanie musi różnić się od ćwiczeń stosowanych wobec innych kategorii polskich słów. Potrzeba refleksji, jakie nazwy i typy nazw wprowadzić na danym etapie edukacji (według podstawy programowej - począwszy od klasy VII-VIII), jakie cele starać się osiągnąć oraz jakie rodzaje ćwiczeń w związku z tym stosować.

\section{Jak pracować nad i z odmianą polskich nazw miejscowych}

Bogactwu prac dotyczących polskiej fleksji ${ }^{9}$ nie towarzyszy obfitość opracowań mówiących, jak uczyć o niej w szkole ${ }^{10}$. Jedną z przyczyn jest zapewne to, że w wieku wczesnoszkolnym są opanowane podstawy systemu fleksyjne-

6 Stownik nazw miejscowości i mieszkańców z odmiana i poradami językowymi, red. M. Łaziński, Warszawa 2007.

7 W tym zawiera się 915 miast i ponad 43 tys. wsi. Oprócz nich wykaz wymienia jeszcze 21 innych typów nazw miejscowych: część miasta, część wsi, osiedle, osiedle wsi, kolonia, część kolonii, kolonia wsi, kolonia kolonii, kolonia osady, osada, część osady, osada wsi, osada kolonii, osada osady, przysiółek, przysiółek wsi, przysiółek kolonii, przysiółek osady, osada leśna, osada leśna wsi, schronisko turystyczne.

8 Stownik nazw miejscowości...

9 Na przykład M. Bańko, Wykłady z polskiej fleksji, Warszawa 2012; J. Tokarski, Fleksja polska, Warszawa 2001; J. Porayski-Pomsta, Odmiana wyrazów, [w:] Nauka o języku dla polonistów, red. S. Dubisz, Warszawa 1999, s. 188-253; H. Jadacka, Kultura języka polskiego. Fleksja, słowotwórstwo, składnia, Warszawa 2005.

10 Na przykład w poradniku ABC metodyki języka polskiego brak osobnego hasła „fleksja” czy „odmiana wyrazów”; ćwiczenia z odmiany są podkategorią ćwiczeń gramatycznych (przykładowe ćwiczenie: „uzupełnij tekst rzeczownikiem w odpowiednim przypadku”) — por. M. Nagajowa, ABC metodyki języka polskiego dla początkujących nauczycieli, Warszawa 1990. 
$\mathrm{go}^{11}$. W późniejszej praktyce szkolnej odmianie poświęca się mniej czasu, skupia zaś na charakterystyce poszczególnych części mowy i przysługujących im kategorii gramatycznych. W zakresie rzeczownika zwraca się uwagę na rozmaite osobliwości w jego odmianie i formy sprawiające szczególne kłopoty, ograniczając się jednak do nazw pospolitych ${ }^{12}$. W efekcie PNM mogą być i dla ucznia, i dla nauczyciela pierwszą w edukacji szkolnej okazją do naprawdę bliskiego spotkania z praktycznymi niuansami odmiany rzeczowników.

Podstawowe zasady wymieniane w związku z dydaktyką fleksji to zasada stopniowania trudności oraz łączenia teorii z praktyką ${ }^{13}$. Obie należy bezwzględnie stosować podczas pracy z PNM. Stopniowanie trudności wiąże się z selekcją materiału - przygotowując wiadomości i ćwiczenia, warto uwzględnić:

a) obszerność grupy nazw danego typu, decydującą o rozpowszechnieniu wzorca odmiany — istotniejsze wydaje się przyjrzenie się w pierwszej kolejności typom liczniej reprezentowanym, potem można przejść do mniej popularnych typów czy jednostkowych okazów;

b) popularność nazw — więcej uwagi poświęcić tym, które z określonych przyczyn są częściej wykorzystywane, na przykład z uwagi na wielkość miejscowości, jej szczególne znaczenie w skali kraju bądź bliskość względem naszych uczniów (choć nie zawsze łatwo ocenić popularność nazwy, a poza tym częściej słyszane nazwy są zapewne lepiej opanowane).

Przewidywany stopień trudności danej nazwy można uznać w znacznej mierze za pochodną dwóch wymienionych czynników — na przykład odmiana nazwy Kraków jest łatwa ze względu na liczebność grupy, do której należy (powszechność PNM zakończonych na -ów), oraz ze względu na ogromną popularność tej nazwy; fleksja nazwy Rudy-Rysie będzie trudna z powodu jej nietypowości (niełatwo wskazać znane, analogicznie zbudowane nazwy) oraz zdecydowanie niższej jej znajomości (chyba że leży w naszej okolicy).

Należy również pamiętać o znacznym zróżnicowaniu częstości używania poszczególnych form nazw. Najczęściej występują formy dopełniacza i miejscownika, rzadziej zaś na przykład celownika, przez co potrafi on sprawić kłopoty nawet przy nazwach dobrze znanych, jak Wrocław czy Piotrków. Wydaje się, że przy nazwach mniej popularnych w pierwszej kolejności wypada zwrócić uwagę na formy najczęściej wykorzystywane (gdyż będą one najbardziej przydatne),

11 Stanisław Grabias pisze: „Normalnie rozwijające się dziecko w wieku sześciu lat ma opanowaną sprawność systemową i potrafi budować zdania gramatycznie poprawne w warunkach codziennej komunikacji”, idem, Język w zachowaniach społecznych, Lublin 1997, s. 319.

12 Por. np. H. Synowiec, Fleksja i nauka o częściach mowy, [w:] Wiedza o języku polskim $w$ zreformowanej szkole, red. A. Mikołajczuk, J. Puzynina, Warszawa 2004, s. 141-161. Autorka zaprojektowała siatkę pojęć i terminów związanych z fleksją w szkole oraz objaśniła je w słowniku. Wśród proponowanych treści znalazły się osobliwości w odmianie rzeczownika, jednak mówi się tylko o nazwach pospolitych, mimo że niektóre wymieniane zjawiska dotyczą także nazw własnych, w tym miejscowych — na przykład odmiana przymiotnikowa rzeczowników.

13 Ibidem, s. 142. 
a przy nazwach stosunkowo popularnych — na formy rzadsze (bo te najczęstsze są zapewne opanowane).

Nie wydaje się konieczne pokazywanie uczniom pełnej klasyfikacji nazw miejscowych (według rodzajów gramatycznych czy budowy słowotwórczej), ponieważ mogą być wtedy przytłoczeni samą liczbą typów, a przełączanie się między wieloma paradygmatami okaże się dla wielu z nich zbyt trudne. W pełnej klasyfikacji siłą rzeczy znalazłyby się też te typy PNM, o których nie trzeba mówić, gdyż nie sprawiają zwykle poważniejszych trudności fleksyjnych (na przykład nazwy zakończone na -ów, -ice/-yce). Nie chodzi przecież o przekazanie uczniom typologicznej wiedzy, ,jak z gramatycznego punktu widzenia dzieli się nazwy miejscowe?", tylko o informacje, ,jakie typy nazw miejscowych sprawiają trudności w odmianie i jak sobie z nimi poradzić". Szczególną uwagę warto więc zwrócić na początku na te sytuacje, które są kłopotliwe, acz nie najbardziej wymagające, i dotyczą znacznej liczby PNM, na przykład:

a) różnorodność sposobów odmiany nazw zakończonych na -e, wynikająca z odmiennego rodzaju i/lub liczby poszczególnych nazw; odmiana przymiotnikowa dotycząca części tego typu nazw: mających liczbę pojedynczą (na przykład Zakopane) i mnogą (na przykład Końskie), które użytkownicy spontanicznie odmieniają rzeczownikowo;

b) odmiana rzeczownikowa części nazw zakończonych na -a (typu Włoszczowa czy Jabłonna), które użytkownicy mają skłonność odmieniać przymiotnikowo;

c) oboczność form dopełniaczowych różnych nazw — w liczbie pojedynczej (e ruchome, -a/-u w nazwach rodzaju męskiego) i w liczbie mnogiej (- $\phi /-o ́ w)^{14}$.

Dobierając przykłady do ćwiczeń, warto dążyć do tego, by w większości nie były one indywidualnościami, lecz reprezentowały pewne typy nazw i problemów (na przykład wyżej wymienione), dzięki czemu operacje wykonywane na kilku przykładach przydadzą się potem do wszystkich nazw w określonej grupie.

Wielość typów deklinacyjnych PNM i nieregularności w odmianie skłania też, by przewartościować cele pracy — równie ważne jak cel pragmatyczny (czyli rozwijanie umiejętności odmiany tych nazw) może być:

a) rozwijanie umiejętności logicznego myślenia, analizy, wyciągania wniosków - jako kompetencji uniwersalnych;

b) zapoznanie uczniów ze sposobami radzenia sobie z różnymi nietypowymi i trudn(iejsz)ymi sytuacjami, na przykład przez korzystanie ze słowników i innych wiarygodnych źródeł informacji.

14 Na proponowanej liście ,priorytetów” nieprzypadkowo brakuje dwóch zagadnień, po które chętnie sięga się w związku z tematem: a) istnienia i odmiany nazw żeńskich zakończonych na spółgłoskę (typ Bydgoszcz, Gołdap); b) istnienia nazw męskich o odmianie miękkotematowej (typu Wrocław, Radom). Powodem tej decyzji jest stosunkowo mała liczba tego typu nazw, z których część jest w dodatku powszechnie znana, a więc zapewne nie sprawia (większych) trudności. 
W dalszej części artykułu przedstawiam kilka propozycji sposobów pracy i ćwiczeń realizujących te dwa i jeszcze inne cele, odwołujących się do przykładów PNM związanych głównie z wcześniej wymienionymi zagadnieniami.

\subsection{Uczyć logicznie myśleć}

Ćwiczenia w odmianie PNM znakomicie potwierdzają tezę, że „obserwacja i analiza zjawisk językowych rozwija zdolność logicznego myślenia, myślenia abstrakcyjnego, umiejętność dokonywania manipulacji abstrakcyjnymi konstruktami, dostrzegania relacji między teorią a użyciem"15.

Podstawową operacją jest odwoływanie się do analogii. Przez analogię rozumie się świadomość podobieństwa przy świadomości istniejących różnic. Jej rola jest nie do przecenienia w rozwoju sprawności mowy — pozwala uwolnić się od pamięciowej reprodukcji form, dokonywać generalizacji i radzić sobie w nowych sytuacjach ${ }^{16}$. Przywołanie systemowych analogii bardzo się przydaje, gdy użytkownik napotyka mało znaną PNM — dużym ułatwieniem jest wtedy informacja, że odmienia się ona identycznie jak słowo powszechnie znane i niesprawiające w związku z tym żadnych (lub większych niż zwykle) kłopotów. Potrzebne wzorce odmiany są bowiem opanowane i stosowane intuicyjnie, należy jedynie związać je z omawianymi PNM. Uczniowi bardziej pomoże w tym konkretny, znajomy wzór (w postaci odmiany konkretnej nazwy własnej czy pospolitej) niż opis modelu oparty na abstrakcyjnej terminologii, zwykle dla niego niezrozumiałej (typu odmiana męska twardotematowa, odmiana żeńska miękkotematowa, deklinacja przymiotnikowa itp. ${ }^{17}$ ). Szczególnie niecelowe jest obciążanie ucznia terminologią tam, gdzie bez większego kłopotu radzi sobie bez niej.

Propozycje wykorzystania analogii przedstawiają ćwiczenia 1 i 2.

\section{Ćwiczenie 1}

W odmianie mniej znanej nazwy miejscowej może pomóc odwołanie się do podobnie zakończonej nazwy dobrze znanej. Podaj poprawne formy pogrubionych nazw.

a) Plaw odmienia się jak Wrocław, czyli jadę do

b) Bardo odmienia się jak Kutno, czyli mieszkam w

c) Jagodne odmieni się jak Zakopane, czyli pracuję w ...........

d) Olszowa odmienia się jak Częstochowa, czyli nocuję w .........

15 M. Szymańska, Między nauka o języku a rozwijaniem języka. Koncepcje ksztatcenia językowego na przełomie XX i XXI wieku, Kraków 2016, s. 262.

16 I. Kaproń-Charzyńska, J. Kamper-Warejko, Ksztaltowanie się systemu językowego w zakresie kategorii przypadka rzeczowników u dzieci 5- i 6-letnich, Torun 2016, s. 23-25.

17 Autorka rozdziału Fleksja i nauka o częściach mowy w tomie Wiedza o języku polskim $w$ zreformowanej szkole nie przewidywała pojawienia się tego typu terminologii na żadnym etapie edukacji. 


\section{Ćwiczenie 2}

W odmianie mniej znanej nazwy miejscowej może pomóc odwołanie się do podobnie zakończonej nazwy pospolitej. Wypełnij poniższą tabelę.

\begin{tabular}{|l|l|l|l|}
\hline & \multicolumn{1}{|c|}{ Nazwy miejscowe } & \multicolumn{1}{|c|}{$\begin{array}{c}\text { Tak samo odmieniająca się } \\
\text { nazwa pospolita }\end{array}$} & \multicolumn{1}{|c|}{$\begin{array}{c}\text { Przykład użycia } \\
\text { nazwy miejscowej }\end{array}$} \\
\hline a) & Baniocha, Przysucha & macocha & Opowiadam o ... \\
\hline b) & Jabłonna, Trzcianna & wanna & Widzę ... \\
\hline c) & Jeżowe, Bogate & gotowe $(\mathrm{lp.})$ & Droga do ... \\
\hline d) & Trzebież, Chodzież & grabież & Nie słyszałem o ... \\
\hline e) & Charzykowy, Rydułtowy & krowy $(\mathrm{lm})$. & Mieszkam w ... \\
\hline
\end{tabular}

W ćwiczeniu 1 mało znane nazwy miejscowe zestawiono z nazwami uznanymi za powszechnie znane. Pracując z uczniami starszymi (szkoła ponadpodstawowa) lub zdolniejszymi, można też nie podsuwać im gotowych analogii, lecz poprosić o samodzielne ich wskazanie ${ }^{18}$.

Punkt a) przypomina, że nazwy zakończone na -aw najczęściej odmieniają się miękkotematowo jak niesprawiający trudności Wrocław. W punkcie b) porusza się problem fleksji nazw zakończonych na -o, zestawiając mniej znane nazwy z popularn(iejsz)ym określeniem Kutno; szczególnie kłopotliwy bywa miejscownik (np. mieszkam w...), gdyż zachodzą w nim alternacje tematyczne. Punkt c) kieruje uwagę na najbardziej (teoretycznie) problematyczną formę miejscownika nazw w lp. rodzaju niejakiego zakończonych na -e, która różni się od współczesnej postaci przymiotnikowej. W punkcie d) pojawiły się nazwy rodzaju żeńskiego zakończone na -owa, które użytkownik jest skłonny odmieniać przymiotnikowo, podczas gdy w niektórych sytuacjach należy to robić rzeczownikowo. W zrozumieniu i zapamiętaniu właściwego postępowania może pomóc identycznie zakończona nazwa Czestochowa, z której odmianą nie powinno być trudności.

W ćwiczeniu 2 podano nazwy pospolite odmieniające się analogicznie jak przywołane PNM. Uczeń na pewno zna te słowa i potrafi je bez kłopotu odmienić, głównym zadaniem jest więc świadome przeniesienie na nową formę językową algorytmu na co dzień używanego automatycznie, bezrefleksyjnie. Punkt a) dotyczy stosunkowo łatwej nazwy rodzaju żeńskiego zakończonej na -a; jego zadaniem jest przypomnienie, że w formie miejscownika nazwy wsi Baniocha musi zajść typowa dla polszczyzny oboczność tematyczna ch : sz, powszechnie i spontanicznie stosowana w nazwach pospolitych typu blacha, pacha czy macocha. Punkt b) jest okazją do ukazania, że wiele PNM, które ze względu na ich formę (zakończenie np. na -na) mamy skłonność odmieniać przymiotnikowo, deklinu-

18 Jest to jednak nieco ryzykowne, gdyż wiele PNM zachowuje się nietypowo, na przykład pod wpływem lokalnego uzusu. 
ją się jak rzeczowniki. Nie sposób tu wskazać precyzyjnej zasady ${ }^{19}$, ale chodzi o rozbudzenie świadomości, że ,zachowywanie odmiany rzeczownikowej nazw żeńskich wyglądających jak przymiotniki świadczy o staranności języka i szacunku dla tradycji”"20. Punkt c) pokazuje typową odmianę przymiotnikową PNM, a punkt d) pozwoli zwrócić uwagę na grupę nietypowych PNM, mających rodzaj żeński mimo spółgłoskowego zakończenia. Z kolei w punkcie e) widać, jak utworzyć miejscownik od dość kłopotliwych nazw zakończonych na -owy i mających liczbę mnogą.

Nieocenioną pomocą w stosowaniu analogii — zarówno w sytuacjach dydaktycznych, jak i życiowych — jest indeks a tergo (lista słów ułożonych alfabetycznie według zakończenia). Można go znaleźć między innymi w Słowniku nazw miejscowości i mieszkańców oraz w elektronicznej wersji Uniwersalnego słownika języka polskiego (który jednak zawiera stosunkowo mało PNM).

Innym typem ćwiczenia zmuszającym do analizy materiału językowego oraz wyciągania logicznych wniosków jest ćwiczenie 3 .

\section{Ćwiczenie 3}

Podaj poprawną formę nazwy miejscowej, korzystając z dwóch już podanych.

a) Małogoszcz — do Małogoszcza - w ...

b) Krasnystaw — w Krasnymstawie — do ...

c) Miętne - w Miętnem - do ...

d) Kulesze - do Kulesz - w ...

e) Wysokie — do Wysokiego — w ...

f) Wysokie — do Wysokich — w ...

Istotą ćwiczenia 3 jest to, że oprócz formy mianownikowej podaje ono jedną formę przypadka zależnego danej nazwy (najbardziej przydatne i naturalne — dopełniacz i miejscownik). W takiej sytuacji logicznie rozumujący człowiek może ustalić poprawną szukaną formę wyłącznie na podstawie danych w ćwiczeniu (o ile oczywiście wcześniej przyswoił polskie wzorce fleksyjne). Nie byłoby to możliwe, gdyby znał tylko mianownik (jak to jest zazwyczaj) - dla wielu przykładów mógłby wtedy jedynie wymienić możliwe odpowiedzi, ale do ostatecznego wyboru jednej właściwej potrzebowałby na przykład słownika. W przykładzie a) dzięki formie zależnej uczeń może dostrzec, że mało znana nazwa Małogoszcz jest rodzaju męskiego (inaczej niż szerzej znana Bydgoszcz, mająca rodzaj żeński) i dzięki temu utworzyć poprawną formę w Małogoszczu. Przykład b) jest okazją do zwrócenia uwagi na fleksję wewnętrzną niektórych złożeń (dzięki podaniu jednej formy zależnej od razu widać, że takowa zachodzi), przykłady c) i d) pozwalają dostrzec, że odmiennie zachowują się nazwy miejscowe tak samo zakończone

19 Wątpliwości nie dotyczą PNM tożsamych ze współcześnie używanymi przymiotnikami, jak np. Wiśniowa, Sucha, Biała.

20 Stownik nazw miejscowości..., s. XVII. 
(na -e), a para przykładów e) i f) pokazuje, że dwie nazwy tak samo wyglądające w mianowniku mogą się inaczej odmieniać.

Dodatkową zaletą tego typu ćwiczenia jest to, że można w nim wykorzystać każdą PNM, gdyż jego głównym celem jest wykonanie określonej operacji myślowej. Poprawnej odpowiedzi można udzielić mimo nieznajomości czy nietypowości nazwy — wystarczy przeprowadzić odpowiednie rozumowanie i odwołać się, mniej lub bardziej świadomie, do wzorców fleksyjnych znanych każdemu użytkownikowi polszczyzny. Pracuje się tutaj metodą problemową, kiedy „poszukiwanie rozwiązania problemu stawia ucznia w roli badacza języka, poszukiwacza rządzących w nim reguł"21.

W ćwiczeniach 1-3 na pierwszym planie nie jest zatem zapamiętanie wzorca odmiany konkretnych, jednostkowych nazw, lecz ukazywanie sposobów radzenia sobie z tego typu trudnościami, a także rozwijanie przy użyciu PNM umiejętności ogólniejszych: analizy formy językowej, naśladowania wzorów, dostrzegania i wykorzystania analogii. Oczywiście równocześnie uczeń może opanować odmianę nazw Pław czy Charzykowy, jednak jest to cel fakultatywny (być może uczeń nigdy później nie użyje tych nazw i ich form).

\subsection{Uczyć porzucać schematy}

Wiele mniej typowych PNM otwiera pole do ćwiczeń związanych z porzucaniem schematów i przełamywania nawyków. Nazwy miejscowe pozwalają myśleć na nowo o czymś, co robi się mechanicznie i bezrefleksyjnie.

Pierwszą sprawą jest przezwyciężenie nadmiernego przywiązania do mianownika. Jak wskazywałem w części 2, forma mianownikowa często niesie mniej ważnych informacji gramatycznych o nazwie miejscowej niż przypadki zależne. W przykładach typu Podjadę do (Dtugie) ......... czy Byliśmy w (Świnna) ......... podana forma mianownikowa nie pozwala ustalić wzorca odmiany użytych nazw miejscowych, umożliwia jedynie wskazanie różnych prawdopodobnych wariantów (Dlugiego - Dlugich - Dlugi; Świnnie - Świnnej). Żeby wykonać takie ćwiczenie, trzeba poszukać informacji o sposobie odmiany nazw Dlugie czy Świnna. Jest to zatem w praktyce ćwiczenie bardziej na wyszukiwanie potrzebnej informacji w wiarygodnych źródłach niż na sprawność gramatyczną — równie dobrze mogłoby mieć postać: Sprawdź w słowniku, jak odmienia się nazwa miejscowa ... (o ile w ogóle udałoby się znaleźć taką informację o danej nazwie miejscowej).

W wielu sytuacjach łatwiej z formy zależnej odtworzyć mianownik (i inne formy zależne) niż odwrotnie. Wskazane jest zatem pokazywanie form niemianownikowych, jak proponują to przykładowe ćwiczenia 4 i 5 .

${ }^{21}$ M. Szymańska, op. cit., s. 268. 


\section{Ćwiczenie 4}

Podkreśl w zdaniach te nazwy miejscowe, które odmieniają się jak przymiotniki (np. kolorowa, zielone). Podaj formy mianownikowe podkreślonych nazw.

a) Pojechaliśmy na targ w Sochaczewie.

b) Mieszkali tuż obok Nowej Iwicznej.

c) Rodzice zatrzymali się niedaleko Zakopanego.

d) Nigdy nie byliśmy w Kielcach.

e) Podróż do Mrągowa trwa dwie godziny.

f) W Nowem jest bardzo nowoczesny hotel.

\section{Ćwiczenie 5}

Podkreśl w zdaniach te nazwy miejscowe, które mają liczbę mnogą. Podaj formy mianownikowe podkreślonych nazw.

a) Pojechaliśmy na targ w Końskich.

b) Mieszkali tuż obok Międzyzdrojów.

c) Niedaleko Wejherowa jest piękne jezioro.

d) W Jedwabnem jest bardzo dobra restauracja.

e) Nigdy nie byliśmy w Strzelcach.

f) Podróż do Świecia trwała dwie godziny.

Gdyby w powyższych ćwiczeniach podać nazwy w mianowniku, do poprawnej odpowiedzi potrzebne byłoby (przynajmniej w niektórych punktach) wsparcie, na przykład słownikowe. Użyta forma niemianownikowa pokazuje jasno, która nazwa ma odmianę rzeczownikową, a która przymiotnikową (ćwiczenie 4), która jest w liczbie pojedynczej, a która w mnogiej (ćwiczenie 5) ${ }^{22}$. Przykłady, które powinny zostać podkreślone w ćwiczeniu 5, reprezentują zarówno odmianę przymiotnikową - a), d), jak i rzeczownikową — b) i e). Gdyby to okazało się zbyt trudne, można stworzyć ćwiczenie zawierające nazwy odmieniające się według jednego wzorca.

Odrzucanie przyzwyczajeń jest niezbędne także wtedy, gdy pracuje się z takimi PNM, które są tożsame z nazwami pospolitymi lub własnymi innego typu, ale odmieniają się inaczej niż one. To zadanie raczej dla starszych i/lub zdolniejszych uczniów, ponieważ zastąpienie mocno utrwalonego paradygmatu innym jest sporym wyzwaniem intelektualnym. Ćwiczenie z takimi nazwami może wyglądać na przykład tak:

\section{Ćwiczenie 6}

Podaj poprawną formę nazwy miejscowej, korzystając $\mathrm{z}$ dwóch już podanych.

22 Nie znaczy to, że ćwiczenia polegające na podaniu odpowiedniej formy na podstawie postaci mianownikowej są całkowicie nieprzydatne. Można je stosować na przykład w czasie powtarzania wiadomości i utrwalania zdobytych umiejętności lub też podczas pracy ze słownikiem lub inną pomocą. 
a) Rysie — do Rysia — w .............

b) Jeziora — do Jeziory — w ............

c) Jarosław - w Jarosławiu — do

d) Lalkowy — w Lalkowach — do

e) Grabie - w Grabiu - do

f) Orla - do Orli - przez

g) Królowe - do Królowego - w

Ćwiczenie 6 opiera się na schemacie już ukazanym w ćwiczeniu 3, zawiera jednak inne, specyficzne przykłady. Forma do Rysia wskazuje, że należy odrzucić nasuwającą się spontanicznie myśl, że nazwa Rysie jest liczbą mnogą rzeczownika ryś. W rzeczywistości ma ona rodzaj nijaki i liczbę pojedynczą (jak na przykład wtosie) - i taka diagnoza pozwoli utworzyć poprawną formę w Rysiu. Nazwa Jeziora w punkcie b) nie jest liczbą mnogą od rzeczownika jezioro, lecz ma rodzaj żeński i liczbę pojedynczą (jak na przykład sfora lub nora). W punkcie c) trzeba porzucić typowy sposób odmiany imienia Jarosław i uwzględnić historyczną miękkość końcowej spółgłoski nazwy miejscowej. Punkt d) zawiera nazwę Lalkowy, którą spontanicznie odbiera się jak przymiotnik rodzaju męskiego (jak na przykład zdrowy, surowy). Obserwacja formy $w$ Lalkowach przekonuje jednak, że jest to zły trop — w rzeczywistości analizowana nazwa ma liczbę mnogą i odmienia się jak na przykład głowy. W punkcie e) zachodzi podobne zjawisko jak w punkcie a) — chodzi o to, by odkryć, że Grabie to nazwa rodzaju nijakiego w liczbie pojedynczej, a nie plurale tantum jak tożsamy budową rzeczownik pospolity. Przykład f) opiera się na nazwie Orla, która wbrew pozorom nie jest przymiotnikiem rodzaju żeńskiego (skoro nie utworzono formy do Orlej), a ukazana w przykładzie g) forma do Królowego uprawnia do wniosku, że Królowe to nazwa rodzaju nijakiego i w liczbie pojedynczej analogiczna na przykład do $Z a-$ kopane, nie zaś liczba mnoga od królowa.

W przypadku PNM homonimicznych względem nazw pospolitych jeszcze bardziej istotna jest uważna obserwacja form przypadków zależnych, ukazują one bowiem odmienność fleksyjną nazwy miejscowej.

Działania związane z PNM mogą mieć także charakter twórczy. Nic nie stoi na przeszkodzie, by uczniowie sami wyszukiwali na mapie czy w internecie ciekawe bądź zabawne nazwy miejscowe, zadawali sobie nawzajem zagadki dotyczące sposobu ich zastosowania w zdaniu. Mogą także tworzyć własne, fikcyjne nazwy — jak w ćwiczeniu 7.

\section{Ćwiczenie 7}

Wyobraź sobie krainę, której wszyscy mieszkańcy są wielkimi miłośnikami sportu. Zaproponuj kilka nazw miast, które mogłyby istnieć w tej krainie.

Wymyślanie nazw miejscowych pozwoli zaobserwować istnienie odpowiednich wzorców słowotwórczych i może stać się okazją do rozmowy o pochodzeniu 
PNM. Do nowo utworzonych nazw trzeba potem dobrać odpowiednie wzorce odmiany; jeśli uczniowie wykorzystają tylko najczęstsze modele nazw, niesprawiające kłopotów w odmianie (typu Tenisowo, Hokejów), trudniejsze może zaproponować nauczyciel (na przykład Mistrzowskie, Zawody Wielkie, Medale-Puchary).

\subsection{Uczyć korzystać ze źródeł}

Niezmiernie istotnym celem pracy z PNM jest wyrobienie nawyku korzystania z dostępnych pomocy - słowników czy wykazu nazw urzędowych. Tylko one w wielu wypadkach gwarantują niezbędne informacje, ćwiczenia powinny zatem zapoznawać uczniów z wiarygodnymi źródłami wiedzy oraz uczyć, jak z nich efektywnie korzystać.

Przydatne źródła ukazujące sposoby poprawnego używania nazw miejscowych to ${ }^{23}$ :

a) Stownik nazw miejscowości i mieszkańców z odmiana i poradami językowy$m i$, zawierający około 7400 polskich nazw miejscowych, odnoszących się w większości do miejscowości mniejszych i mniej popularnych; prócz informacji o sposobie odmiany słownik podaje nazwy mieszkańców, mieszkanek oraz przymiotnik odmiejscowy, w słowniku zawarto też niezmiernie przydatny indeks a tergo;

b) Wykaz urzędowych nazw miejscowości i ich części ogłoszony 19 października 2015 roku na podstawie obwieszczenia Ministra Administracji i Cyfryzacji; w spisie zawarto wszystkie nazwy miejscowe w Polsce, podano formę dopełniacza, a także przymiotnika odmiejscowego;

c) Stownik nazw własnych, zawierający wybrane PNM, podający ich formy gramatyczne, a także nazwy mieszkańców, mieszkanek oraz przymiotnik odmiejscowy;

d) Kultura języka polskiego. Fleksja, stowotwórstwo, składnia — podręcznik akademicki poświęcony poprawności językowej, zawierający ogólne zasady i przykłady odmiany PNM, a także tworzenia przymiotników odmiejscowych;

e) Poradnik prof. Markowskiego — poradnik językowy, zawierający ogólne zasady i przykłady odmiany PNM, a także tworzenia nazw mieszkańców, mieszkanek oraz przymiotników odmiejscowych;

f) Wielki stownik poprawnej polszczyzny, zawierający wybrane PNM, podający ich wybrane formy gramatyczne, a także (jako osobne hasła) nazwy mieszkańców, mieszkanek oraz przymiotnik odmiejscowy;

g) Uniwersalny stownik języka polskiego, zawierający wybrane PNM (tylko większe miasta), podający ich wybrane formy gramatyczne, a także (jako osobne hasła) nazwy mieszkańców, mieszkanek oraz przymiotnik odmiejscowy; w wersji elektronicznej zawiera też indeks a tergo;

23 Pełny opis bibliograficzny wymienianych pomocy znajduje się na końcu artykułu. 
h) internetowa poradnia językowa $\mathrm{PWN}^{24}$, dział „nazwy własne” — eksperci odpowiadają na pytania, na które często trudno znaleźć odpowiedź w słownikach.

Pomoce warto wykorzystywać jak najczęściej — i podczas szukania poprawnej formy jednostkowej nazwy, i przy opanowywaniu ogólnych zasad. Przykładowe ćwiczenia:

\section{Ćwiczenie 8}

Znajdź w słowniku lub wykazie urzędowym trzy polskie nazwy miejscowe będące zrostami jak Biatystok czy Krasnystaw. Zastosuj znalezione nazwy w zdaniach Jadę do... oraz Jestem $w$...

\section{Ćwiczenie 9}

Sprawdź w słowniku lub wykazie urzędowym, które z wymienionych nazw miejscowych odmieniają się jak przymiotniki: Dąbrowy, Lipinki, Babińskie, Lisna, Łyczana.

\section{Ćwiczenie 10}

Odszukaj w odpowiednim słowniku trzy nazwy miejscowe, które odmieniają się tak samo jak nazwa Kielce.

\section{Ćwiczenie 11}

Zastanów się, na czym polega nietypowość odmiany nazwy Tarnobrzeg. W razie trudności skorzystaj z odpowiedniego słownika.

\section{Ćwiczenie 12}

Sprawdź w odpowiednim słowniku, jak odmieniają się złożone nazwy miejscowe pisane z łącznikiem, np. Kędzierzyn-Koźle czy Skarżysko-Kamienna. Ułóż po dwa zdania z tymi nazwami.

Tego typu ćwiczenia pozwalają uczniom uświadomić sobie, jakie typowe problemy napotyka się podczas odmiany wielu PNM i co pomaga je rozwiązywać. Inną ich zaletą jest to, że można (a może wręcz trzeba) uczniom podsuwać bardziej kłopotliwe typy nazw, które byłyby za trudne w innych sytuacjach. Warto też w ten sposób pracować z nazwami, które zachowują się bardzo indywidualnie lub należą do bardzo małej grupy.

\subsection{Zachęcać do wykorzystywania w tekstach}

Posługiwanie się poprawnymi formami PNM jak każde inne zagadnienie gramatyczne warto wiązać z tworzeniem tekstów, w których pojawiają się one w naturalny, a nie wymuszony sposób. Takimi tekstami są na przykład pozdrowienia, zaproszenia, ogłoszenia, jak widać w przykładowych ćwiczeniach:

${ }^{24}$ https://sjp.pwn.pl/poradnia. 


\section{Ćwiczenie 13}

Napisz krótkie pozdrowienia z obozu w miejscowości Łazy. W tekście użyj zwrotu pozdrowienia z...

\section{Ćwiczenie 14}

Kuzyn przygotowujący zaproszenie na przyjęcie weselne w miejscowości Ruciane-Nida pyta cię, jaka będzie poprawna forma tej nazwy w zdaniu: Przyjęcie weselne odbędzie się w...........

\section{Ćwiczenie 15}

Zredaguj krótką informację prasową o targach sztuki ludowej, które są organizowane w miejscowości Wielki Lubień.

Pozdrowienia wykorzystane w ćwiczeniu 13 są też doskonałą okazją, by przećwiczyć i utrwalić formy dopełniaczowe innych typów nazw geograficznych, na przykład łańcuchów górskich, które potrafią sprawiać trudności takie same jak nazwy miejscowe w liczbie mnogiej (Tatr, Pienin — ale Beskidów, Karkonoszy, Bieszczad/Bieszczadów). Ćwiczenie 15 może być pretekstem do przyjrzenia się (nie)obecności e ruchomego w różnych PNM - bez wątpienia w tekście będzie potrzebna forma miejscownika nazwy Lubień.

\subsection{Nie ograniczać się do jednej lekcji}

Z lekcją ściśle poświęconą odmianie nazw geograficznych nie trzeba się spieszyć. Jeśli mają pojawić się przykłady niebanalne, lepiej, by było to w klasie VIII niż VII. Zajęcia o posługiwaniu się PNM nie mogą być natomiast jedynym momentem poświęconym temu zagadnieniu: na różne nazwy miejscowe trzeba zwracać uwagę przy każdej sposobności, na wcześniejszych i późniejszych etapach edukacji. Będzie to wtedy naturalne i łatwiejsze dla uczniów (pojedyncze nazwy nie tworzą natłoku różnych typów i paradygmatów).

Zawsze warto przyglądać się nazwom własnym bliskim uczniom, ich rodzinom i znajomym, co może odbywać się nie tylko na lekcjach polskiego, ale też na przykład na historii, wiedzy o społeczeństwie czy geografii. Inną okazją może być poznawanie życiorysów sławnych postaci, jak pokazuje ćwiczenie zawarte w jednym z podręczników dla klasy VIII:

\section{Ćwiczenie 16}

Sprawdź, gdzie się urodzili twórcy literatury polskiej wskazani w ramce. Sporządź notatkę według wzoru. Wzór: Henryk Sienkiewicz urodził się w Woli Okrzejskiej25.

25 E. Nowak, J. Gaweł, Myśli i słowa. Podręcznik do języka polskiego dla klasy VIII, Warszawa 2018, s. 268. 
Wiele okazji do pracy z PNM stwarza też analiza przekazów medialnych reportaży podróżniczych, relacji czy zwyczajnych newsów. Bieżące wydarzenia nierzadko bowiem sprawiają, że nazwa używana dotąd tylko przez lokalną społeczność zaczyna być nieustannie eksploatowana w mediach i sprawia (przynajmniej na początku) kłopoty fleksyjne. Tak było na przykład w przypadku miasta Włoszczowa (województwo świętokrzyskie) w związku ze sprawą budowy peronu i stacji na trasie Centralnej Magistrali Kolejowej (w 2006 roku) — nie wszyscy dziennikarze (od razu) wiedzieli, że odmienia się ona rzeczownikowo (jak sowa).

\section{Podsumowanie}

Dydaktyka odmiany PNM wymaga starannego doboru materiału, przykładów i metod, by dostosować poziom materiału do możliwości uczniów oraz uniknąć uczenia się poprawnych form na pamięć. Nie musi się ograniczać do realizacji celu oczywistego i najbardziej pragmatycznego, czyli rozwijania umiejętności tworzenia poprawnych form gramatycznych tych nazw, tym bardziej że nie będzie to łatwe, zwłaszcza gdy sięgnie się po przykłady nieco trudniejsze i mniej znane. Z PNM można pracować tak, by osiągać korzyści wielostronne - z jednej strony uczyć o nich samych, z drugiej zaś czynić z nich narzędzia pomagające rozwijać kompetencje nie tylko ściśle językowe. Nazwy miejscowe pozwalają uczyć się porównywania analizowanych elementów, wyciągania wniosków z obserwacji, stosowania analogii czy wyszukiwania informacji i wykorzystywania ich w praktyce. Ćwiczenia dotyczące PNM pomagają stosować rozmaite strategie uczenia (się) o języku, wymieniane przez Jolantę Nocoń — uczeń może być analitykiem konstrukcji językowych, badaczem języka czy wykonawcą działań językowych ${ }^{26}$ — zawsze jednak powinno dominować samodzielne szukanie rozwiązań problemów i zastosowanie umiejętności w praktyce, nie zaś przyswajanie i odtwarzanie kolejnej (w dodatku wyjątkowo kapryśnej) porcji wiedzy o języku. Zapamiętanie poprawnych form PNM i opanowywanie sposobu odmiany może odbywać się niejako ,przy okazji”.

Ukazane w artykule metody pracy mogą być przydatne także podczas omawiania innych zagadnień związanych z PNM. Do analogii warto odwoływać się na przykład podczas ćwiczeń słowotwórczych: przy tworzeniu przymiotników odmiejscowych oraz nazw mieszkanek i mieszkańców.

26 J. Nocoń, Strategie nabywania przez ucznia wiedzy o języku (na przykładzie zadań podręcznikowych), [w:] Wiedza o języku i kompetencje językowe uczniów, red. B. Niesporek-Szamburska, Katowice 2012, s. 30-40. 


\section{Bibliografia}

Bańko M., Wykłady z polskiej fleksji, Warszawa 2012.

Grabias S., Język w zachowaniach społecznych, Lublin 1997.

Grzenia J., Stownik nazw własnych, Warszawa 1998.

Jadacka H., Kultura języka polskiego. Fleksja, stowotwórstwo, składnia, Warszawa 2005.

Kaproń-Charzyńska I., Kamper-Warejko J., Kształtowanie się systemu językowego w zakresie kategorii przypadka rzeczowników u dzieci 5- i 6-letnich, Torun 2016.

Markowski A., Poradnik prof. Markowskiego, Warszawa 2017.

Nagajowa M., ABC metodyki języka polskiego dla początkujących nauczycieli, Warszawa 1990.

Nocoń J., Strategie nabywania przez ucznia wiedzy o języku (na przykładzie zadań podręcznikowych), [w:] Wiedza o języku i kompetencje językowe uczniów, red. B. Niesporek-Szamburska, Katowice 2012, s. 27-43.

Nowak E., Gaweł J., Myśli i słowa. Podręcznik do języka polskiego dla klasy VIII, Warszawa 2018.

Porayski-Pomsta J., Odmiana wyrazów, [w:] Nauka o języku dla polonistów, red. S. Dubisz, Warszawa 1999, s. 188-253.

Rozporzadzenie Ministra Edukacji Narodowej z dnia 14 lutego 2017 r. w sprawie podstawy programowej wychowania przedszkolnego oraz podstawy programowej ksztatcenia ogólnego dla szkoły podstawowej, w tym dla uczniów z niepetnosprawnościq intelektualna w stopniu umiarkowanym lub znacznym, kształcenia ogólnego dla branżowej szkoły I stopnia, ksztatcenia ogólnego dla szkoły specjalnej przysposabiajacej do pracy oraz ksztatcenia ogólnego dla szkoty policealnej (Dz.U. z 2017 r. poz. 356).

Rzetelska-Feleszko E., Nazwy geograficzne, [w:] Wspótczesny język polski, red. J. Bartmiński, Lublin 2001, s. 411-429.

Słownik nazw miejscowości i mieszkańców z odmiana i poradami językowymi, red. M. Łaziński, Warszawa 2007.

Synowiec H., Fleksja i nauka o częściach mowy, [w:] Wiedza o języku polskim w zreformowanej szkole, red. A. Mikołajczuk, J. Puzynina, Warszawa 2004, s. 141-161.

Szymańska M., Między nauka o języku a rozwijaniem języka. Koncepcje kształcenia językowego na przełomie XX i XXI wieku, Kraków 2016.

Tokarski J., Fleksja polska, Warszawa 2001.

Uniwersalny stownik języka polskiego, red. S. Dubisz, Warszawa 2003.

Wielki stownik poprawnej polszczyzny, red. A. Markowski, Warszawa 2008.

Wykaz urzędowych nazw miejscowości i ich części 2015, http://ksng.gugik.gov.pl/urzedowe_nazwy_miejscowosci.php (dostęp: 5.01.2019). 